\title{
Effect of Nanocrystal Distribution on Mechanical Properties of Ti-Based Metallic Glasses
}

\author{
Hirofumi Ito ${ }^{1, * 1}$, Tokujiro Yamamoto ${ }^{2, * 2}$, Masashi Hasegawa ${ }^{2}$ and Akihisa Inoue ${ }^{2}$ \\ ${ }^{1}$ Department of Materials Science, Graduate School of Engineering, Tohoku University, Sendai 980-8579, Japan \\ ${ }^{2}$ Institute for Materials Research, Tohoku University, Sendai 980-8577, Japan
}

\begin{abstract}
$\mathrm{Ti}_{45} \mathrm{Zr}_{5} \mathrm{Cu}_{45} \mathrm{Ni}_{5}$ metallic glasses in which $\mathrm{Ta}$ and $\mathrm{Al}$ were substituted for $\mathrm{Cu}$ were evaluated in terms of mechanical properties, thermal properties and microstructures in order to determine the factors contributing to an improvement in plasticity. Samples are examined by compression testing, differential scanning calorimetry, X-ray diffractometry and electron microscopy. $\mathrm{Mold}_{\text {-cast }} \mathrm{Ti}_{45} \mathrm{Zr}_{5} \mathrm{Cu}_{44} \mathrm{Ni}_{5} \mathrm{Ta}_{1}$ bulk specimens were confirmed to consist of a metallic glass matrix and nanocrystals homogeneously dispersed at high density within the matrix. The yield stresses of both $\mathrm{Ti}_{45} \mathrm{Zr}_{5} \mathrm{Cu}_{45-x} \mathrm{Ni}_{5} \mathrm{Ta}_{x}$ and $\mathrm{Ti}_{45} \mathrm{Zr}_{5} \mathrm{Cu}_{45-x} \mathrm{Ni}_{5} \mathrm{Al}_{x}$ are approximately $1800 \mathrm{MPa}$, and the maximum plastic strain of $3.1 \%$ was obtained for the $\mathrm{Ti}_{45} \mathrm{Zr}_{5} \mathrm{Cu}_{44} \mathrm{Ni}_{5} \mathrm{Ta}_{1}$ specimen. $\mathrm{The} \mathrm{Ti}_{45} \mathrm{Zr}_{5} \mathrm{Cu}_{45-x} \mathrm{Ni}_{5} \mathrm{Al}_{x}$ bulk specimens exhibited poorer plasticity due to the formation of larger crystalline grains. [doi:10.2320/matertrans.MF200616]
\end{abstract}

(Received December 1, 2006; Accepted March 5, 2007; Published May 25, 2007)

Keywords: metallic glasses, mechanical properties, microstructure

\section{Introduction}

Various kinds of Ti-based amorphous aloys and metallic glasses have been developed, ${ }^{1-12)}$ due mainly to the light weight and high corrosion resistance properties of Ti. Tibased metallic glasses are therefore attractive candidates for light-weight, high-strength and biocompatible structural materials. However, fully metallic glasses exhibit only elastic deformation, and activation of many shear bands in metallic glasses is necessary for plastic deformation. The homogeneous dispersion of nanocrystals in metallic glasses is one method for preparing metallic glasses that undergo plastic deformation by the activation of shear bands. Recently, Ti-based bulk metallic glasses exhibiting plastic deformation have been reported, ${ }^{6,11)}$ although the microstructures of the materials have yet to be clarified. If the plastic deformation in Ti-based bulk metallic glasses is caused by the dispersion of nanocrystals, it may be possible to increase the plastic strain by optimizing the density, distribution, and morphology of the nanocrystals.

Many Ti alloys exhibit solid-state phase transformation from austenite $\beta$-Ti to martensite $\alpha^{\prime \prime}$-Ti. When $\beta$ stabilizers are added to the $\mathrm{Ti}$ alloys, the martensite transformation temperature ( $\beta$ transus) decreases with increasing $\beta$ stabilizer content due to stabilization of the $\beta$-Ti phase. When such alloys are quenched, it is expected that $\beta$-Ti nanocrystals will precipitate. In the present study, Ta and $\mathrm{Al}$ as $\beta$ and $\alpha$ stabilizers were substituted for $\mathrm{Cu}$ in $\mathrm{Ti}_{45} \mathrm{Zr}_{5} \mathrm{Cu}_{45} \mathrm{Ni}_{5}$ and the resultant alloys were rapidly quenched to form bulk metallic glasses. The mechanical and thermal properties and microstructures of the glasses were investigated with respect to the dispersion of nanocrystals.

\section{Experimental Procedures}

Ingots with nominal compositions of $\mathrm{Ti}_{45} \mathrm{Zr}_{5} \mathrm{Cu}_{45} \mathrm{Ni}_{5}$,

\footnotetext{
${ }^{* 1}$ Graduate Student, Tohoku University

${ }^{* 2}$ Corresponding author, E-mail: toku@imr.tohoku.ac.jp
}

$\mathrm{Ti}_{45} \mathrm{Zr}_{5} \mathrm{Cu}_{45-x} \mathrm{Ni}_{5} \mathrm{Ta}_{x}$ and $\mathrm{Ti}_{45} \mathrm{Zr}_{5} \mathrm{Cu}_{45-x} \mathrm{Ni}_{5} \mathrm{Al}_{x}(x=1,2,3$, $4,5)$ were prepared by Ar-arc melting, and cylindrical bulk specimens of $1 \mathrm{~mm}$ in diameter and $30 \mathrm{~mm}$ in length were prepared by $\mathrm{Cu}$ mold casting of the ingots. Differential scanning calorimetry (DSC) measurements were performed to determine the glass transition temperature $\left(T_{\mathrm{g}}\right)$, crystallization temperature $\left(T_{\mathrm{x}}\right)$, and supercooled liquid region $\left(\Delta T_{\mathrm{x}}=T_{\mathrm{x}}-T_{\mathrm{g}}\right)$ at a heating rate of $0.67 \mathrm{~K} / \mathrm{s}$. The microstructures of the specimens were characterized by $\mathrm{X}$-ray diffractometry (XRD) using a rotating $\mathrm{Cu}$ anode, scanning electron microscopy (SEM), and transmission electron microscopy (TEM). The mechanical properties of the specimens were examined at room temperature through compression tests at a strain rate of $1 \times 10^{-4} / \mathrm{s}$ using an Instron-type machine.

\section{Results and Discussion}

Figure 1 shows the XRD patterns and DSC traces of $\mathrm{Ti}_{45} \mathrm{Zr}_{5} \mathrm{Cu}_{45-x} \mathrm{Ni}_{5} \mathrm{Ta}_{x}$ bulk specimens. When more than 3 at\% Ta was substituted for $\mathrm{Cu}$, diffraction peaks due to $\beta$ Ti and other unknown phases could be clearly observed in the XRD pattern. According to the presence of these diffraction peaks, the total exothermic heat observed in the DSC measurements was smaller for specimens containing more than 3 at $\%$ Ta. The glass transition was observed for specimens with less than 3 at\% Ta. Even though no diffraction peaks due to crystalline phases were observed in the XRD patterns for $\mathrm{Ti}_{45} \mathrm{Zr}_{5} \mathrm{Cu}_{44} \mathrm{Ni}_{5} \mathrm{Ta}_{1}$ and $\mathrm{Ti}_{45} \mathrm{Zr}_{5} \mathrm{Cu}_{43} \mathrm{Ni}_{5} \mathrm{Ta}_{2}$, it is expected from the weakening of the glass transition with increasing Ta content that the specimens contained nanocrystals.

Figure 2 shows the XRD patterns and DSC traces for $\mathrm{Ti}_{45} \mathrm{Zr}_{5} \mathrm{Cu}_{45-x} \mathrm{Ni}_{5} \mathrm{Al}_{x}$ bulk specimens. For the Al-substituted specimens, diffraction peaks assignable to $\beta$-Ti and other unknown crystalline phases were apparent at $\mathrm{Al}$ of 5 at\%, while no such diffraction peaks were observed for the specimen containing less than 4 at $\% \mathrm{Al}$. The glass transition was clearly observed for the specimen with less than 3 at\% Al. 
(a)

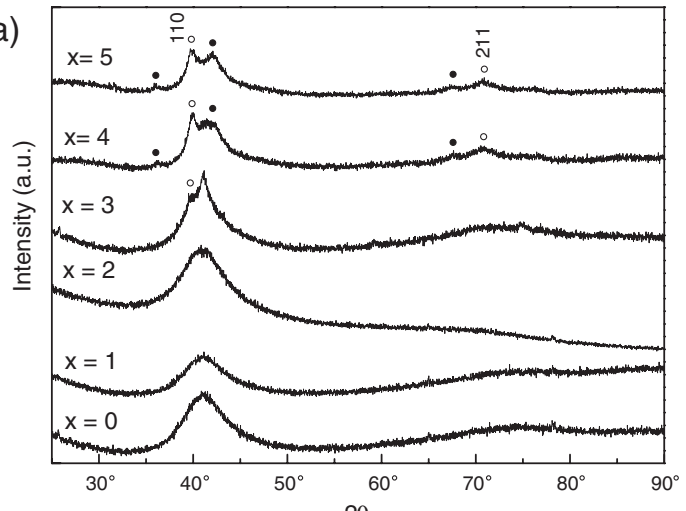

(b)

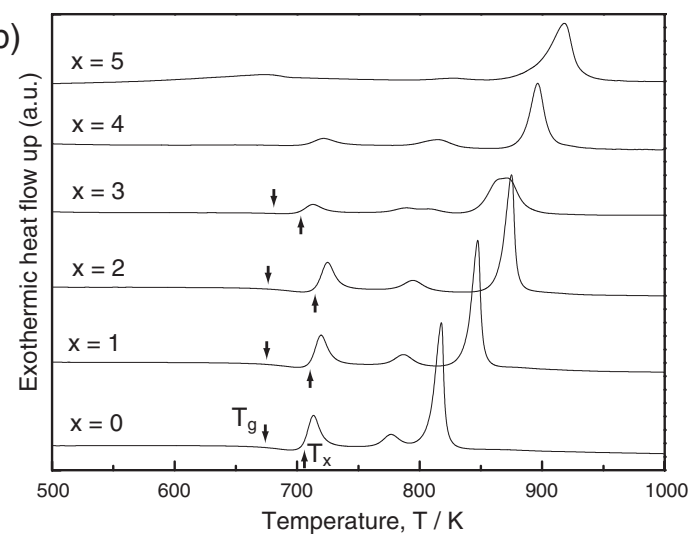

Fig. 1 XRD patterns and DSC traces for $\mathrm{Ti}_{45} \mathrm{Zr}_{5} \mathrm{Cu}_{45-x} \mathrm{Ni}_{5} \mathrm{Ta}_{x}$ bulk specimens. Open and closed circles denote diffraction peaks of $\beta$-Ti and unknown crystalline phases, respectively.

As in the case of $\mathrm{Ti}_{45} \mathrm{Zr}_{5} \mathrm{Cu}_{45-x} \mathrm{Ni}_{5} \mathrm{Ta}_{x}$, the glass transition became weaker with increasing Al content. The heat accompanying the first crystallization at around $725 \mathrm{~K}$ for $\mathrm{Ti}_{45} \mathrm{Zr}_{5} \mathrm{Cu}_{44} \mathrm{Ni}_{5} \mathrm{Al}_{1}, \mathrm{Ti}_{45} \mathrm{Zr}_{5} \mathrm{Cu}_{43} \mathrm{Ni}_{5} \mathrm{Al}_{2}$, and $\mathrm{Ti}_{45} \mathrm{Zr}_{5} \mathrm{Cu}_{42}-$ $\mathrm{Ni}_{5} \mathrm{Al}_{3}$ was much smaller than that for $\mathrm{Ti}_{45} \mathrm{Zr}_{5} \mathrm{Cu}_{45} \mathrm{Ni}_{5}$. If the $\mathrm{Ti}_{45} \mathrm{Zr}_{5} \mathrm{Cu}_{45} \mathrm{Ni}_{5}$ bulk specimen consist entirely of a metallic glass, these results imply that high densities of nanocrystals precipitated in $\mathrm{Ti}_{45} \mathrm{Zr}_{5} \mathrm{Cu}_{44} \mathrm{Ni}_{5} \mathrm{Al}_{1}, \mathrm{Ti}_{45} \mathrm{Zr}_{5} \mathrm{Cu}_{43} \mathrm{Ni}_{5} \mathrm{Al}_{2}$, and $\mathrm{Ti}_{45} \mathrm{Zr}_{5} \mathrm{Cu}_{42} \mathrm{Ni}_{5} \mathrm{Al}_{3}$.

The stress-strain curves for $\mathrm{Ti}_{45} \mathrm{Zr}_{5} \mathrm{Cu}_{45-x} \mathrm{Ni}_{5} \mathrm{Ta}_{x}$ and $\mathrm{Ti}_{45} \mathrm{Zr}_{5} \mathrm{Cu}_{45-x} \mathrm{Ni}_{5} \mathrm{Al}_{x}$ specimens under compression are shown in Fig. 3. All the specimens exhibited yield or fracture stress of approximately $1800 \mathrm{MPa}$. It should be noted that $\mathrm{Ti}_{45} \mathrm{Zr}_{5} \mathrm{Cu}_{45} \mathrm{Ni}_{5}$ also exhibited plastic deformation, implying that even the $\mathrm{Ti}_{45} \mathrm{Zr}_{5} \mathrm{Cu}_{45} \mathrm{Ni}_{5}$ specimen contained nanocrystals. Although both $\mathrm{Ti}_{45} \mathrm{Zr}_{5} \mathrm{Cu}_{44} \mathrm{Ni}_{5} \mathrm{Ta}_{1}$ and $\mathrm{Ti}_{45} \mathrm{Zr}_{5} \mathrm{Cu}_{42}-$ $\mathrm{Ni}_{5} \mathrm{Al}_{3}$ achieved maximum plastic strain, Ta substitution is more effective for increasing the plasticity of $\mathrm{Ti}_{45} \mathrm{Zr}_{5} \mathrm{Cu}_{45} \mathrm{Ni}_{5}$ bulk metallic glasses than Al. The amount of plastic strain in $\mathrm{Ti}_{45} \mathrm{Zr}_{5} \mathrm{Cu}_{44} \mathrm{Ni}_{5} \mathrm{Ta}_{1}$ was $3.1 \%$. To determine why $\mathrm{Ti}_{45} \mathrm{Zr}_{5}-$ $\mathrm{Cu}_{45-x} \mathrm{Ni}_{5} \mathrm{Al}_{x}$ did undergo as much plastic deformation, the microstructures of $\mathrm{Ti}_{45} \mathrm{Zr}_{5} \mathrm{Cu}_{45} \mathrm{Ni}_{5}, \mathrm{Ti}_{45} \mathrm{Zr}_{5} \mathrm{Cu}_{44} \mathrm{Ni}_{5} \mathrm{Ta}_{1}$, and $\mathrm{Ti}_{45} \mathrm{Zr}_{5} \mathrm{Cu}_{42} \mathrm{Ni}_{5} \mathrm{Al}_{3}$ specimens with the largest plastic strain were further examined by TEM.

Figure 4(a) shows the microstructure of $\mathrm{Ti}_{45} \mathrm{Zr}_{5} \mathrm{Cu}_{45} \mathrm{Ni}_{5}$, in which two kinds of precipitates can be observed. This $\mathrm{Ti}_{45} \mathrm{Zr}_{5} \mathrm{Cu}_{45} \mathrm{Ni}_{5}$ specimen essentially consisted of a metallic glass matrix phase and fine nanocrystals, dispersed homoge- (a)

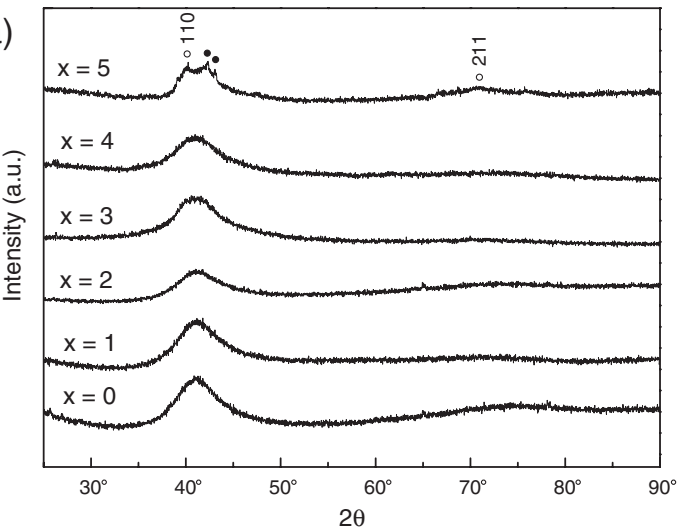

(b)

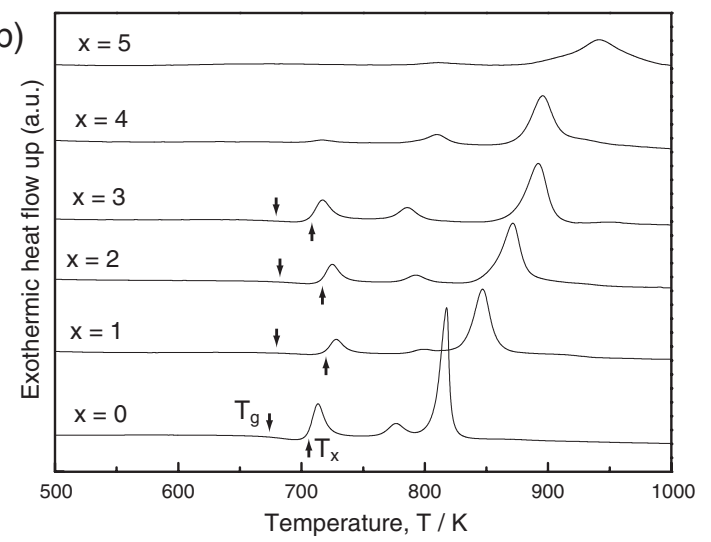

Fig. 2 XRD patterns and DSC traces for $\mathrm{Ti}_{45} \mathrm{Zr}_{5} \mathrm{Cu}_{45-x} \mathrm{Ni}_{5} \mathrm{Al}_{x}$ bulk specimens. Open and closed circles denote diffraction peaks of $\beta$-Ti and unknown crystalline phases, respectively.
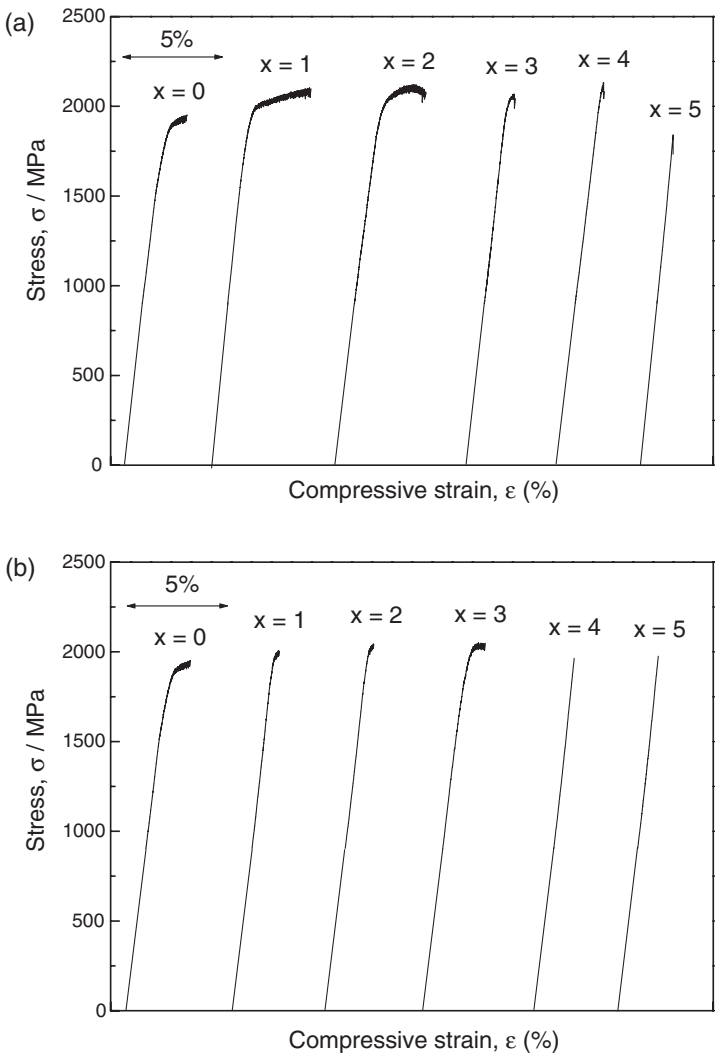

Fig. 3 Stress-strain curves for bulk specimens of (a) $\mathrm{Ti}_{45} \mathrm{Zr}_{5} \mathrm{Cu}_{45-x} \mathrm{Ni}_{5} \mathrm{Ta}_{x}$ and (b) $\mathrm{Ti}_{45} \mathrm{Zr}_{5} \mathrm{Cu}_{45-x} \mathrm{Ni}_{5} \mathrm{Al}_{x}$. 

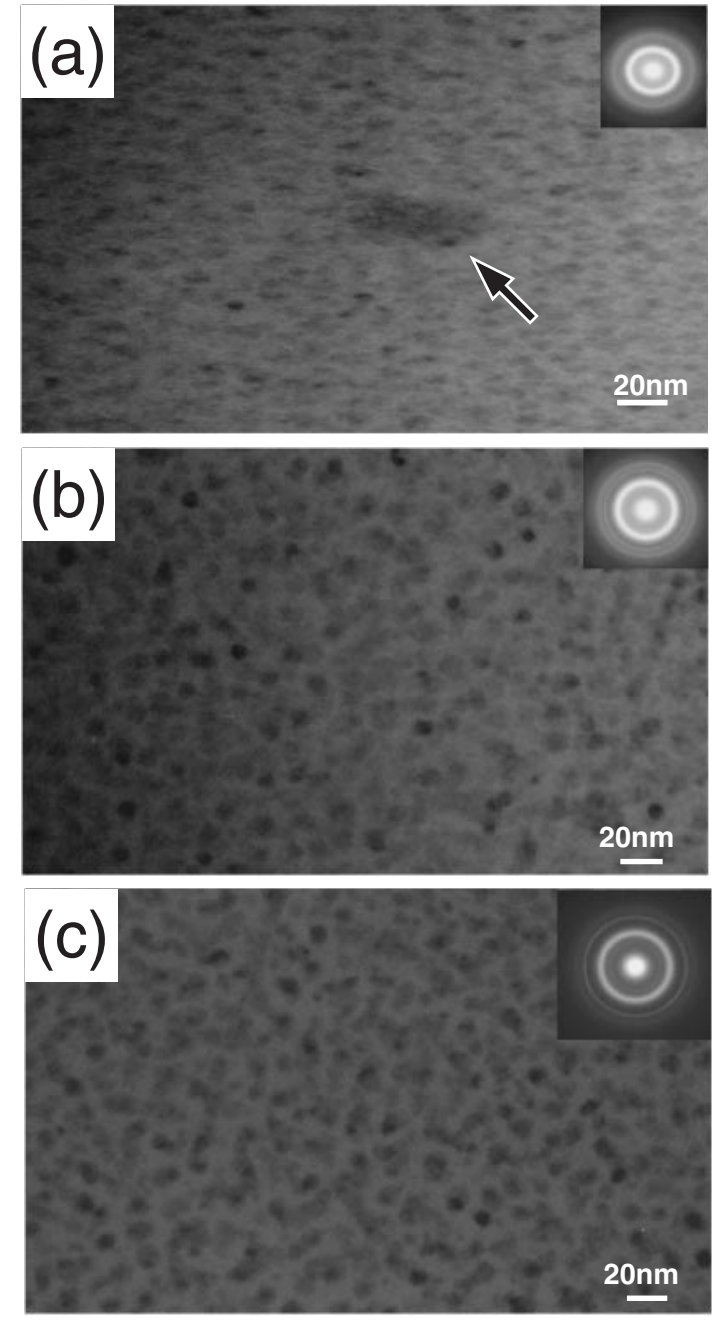

Fig. 4 TEM images and corresponding SAED patterns of bulk specimens of (a) $\mathrm{Ti}_{45} \mathrm{Zr}_{5} \mathrm{Cu}_{45} \mathrm{Ni}_{5}$, (b) $\mathrm{Ti}_{45} \mathrm{Zr}_{5} \mathrm{Cu}_{44} \mathrm{Ni}_{5} \mathrm{Ta}_{1}$, and (c) $\mathrm{Ti}_{45} \mathrm{Zr}_{5} \mathrm{Cu}_{42} \mathrm{Ni}_{5}$ $\mathrm{Al}_{3}$, which exhibited large plastic strain. Arrow in (a) indicates an example of larger nanocrystals.

neously at high density. It has been reported previously that $\mathrm{Ti}_{45} \mathrm{Zr}_{5} \mathrm{Cu}_{45} \mathrm{Ni}_{5}$ forms bulk specimens of up to $3 \mathrm{~mm}$ in diameter consisting of a single glassy phase without crystals. ${ }^{11)}$ Larger nanocrystals of about $40 \mathrm{~nm}$ in diameter were often observed as indicated by the arrow in Fig. 4(a). $\mathrm{Ti}_{45} \mathrm{Zr}_{5} \mathrm{Cu}_{44} \mathrm{Ni}_{5} \mathrm{Ta}_{1}$ specimen also exhibited a homogeneous microstructure consisting of a glass matrix and numerous fine nanocrystals of less than $10 \mathrm{~nm}$ in size (Fig. 4(b)). The larger nanocrystals, which were often found in $\mathrm{Ti}_{45} \mathrm{Zr}_{5} \mathrm{Cu}_{45} \mathrm{Ni}_{5}$, were seldom observed in $\mathrm{Ti}_{45} \mathrm{Zr}_{5} \mathrm{Cu}_{44} \mathrm{Ni}_{5} \mathrm{Ta}_{1} . \mathrm{Ti}_{45} \mathrm{Zr}_{5} \mathrm{Cu}_{42}-$ $\mathrm{Ni}_{5} \mathrm{Al}_{3}$, which although having a similar homogeneous microstructure to $\mathrm{Ti}_{45} \mathrm{Zr}_{5} \mathrm{Cu}_{44} \mathrm{Ni}_{5} \mathrm{Ta}_{1}$, exhibited much less plastic strain.

Figure 5 shows the fracture surfaces of $\mathrm{Ti}_{45} \mathrm{Zr}_{5} \mathrm{Cu}_{44} \mathrm{Ni}_{5} \mathrm{Ta}_{1}$ and $\mathrm{Ti}_{45} \mathrm{Zr}_{5} \mathrm{Cu}_{42} \mathrm{Ni}_{5} \mathrm{Al}_{3}$ observed by SEM. Vein patterns in a fine mesh were prevalent throughout the surface of $\mathrm{Ti}_{45} \mathrm{Zr}_{5}$ $\mathrm{Cu}_{44} \mathrm{Ni}_{5} \mathrm{Ta}_{1}$, while such vein patterns were absent in several areas of the $\mathrm{Ti}_{45} \mathrm{Zr}_{5} \mathrm{Cu}_{42} \mathrm{Ni}_{5} \mathrm{Al}_{3}$ surface as indicated by the arrows. It is considered that the vein-free areas are not metallic glass but large crystalline grains, which were also observed on the fracture surface of other $\mathrm{Ti}_{45} \mathrm{Zr}_{5} \mathrm{Cu}_{42} \mathrm{Ni}_{5} \mathrm{Al}_{3}$ specimens following compression tests. The poor plasticity of $\mathrm{Ti}_{45} \mathrm{Zr}_{5} \mathrm{Cu}_{45-x} \mathrm{Ni}_{5} \mathrm{Al}_{x}$ therefore appears to originate from presence of large crystalline grains, which precipitated in the metallic glass phase.

The above experiments have clarified that high density of fine nanocrystals with uniform dispersion in the metallic glass matrix contribute to the plastic deformation of $\mathrm{Ti}_{45} \mathrm{Zr}_{5} \mathrm{Cu}_{45} \mathrm{Ni}_{5}$-based bulk metallic glasses. The size and morphology of the dispersed nanocrystals also affects the plasticity of the materials in that the plastic strain decreases as the nanocrystals reach approximately $40 \mathrm{~nm}$ in diameter (as in the case of $\mathrm{Ti}_{45} \mathrm{Zr}_{5} \mathrm{Cu}_{45} \mathrm{Ni}_{5}$ ).

\section{Conclusions}

The mechanical and thermal properties and microstructures of $\mathrm{Ti}_{45} \mathrm{Zr}_{5} \mathrm{Cu}_{45} \mathrm{Ni}_{5}$-based metallic glasses were examined with respect to the dispersion and morphology of constituent nanocrystals. $\mathrm{Ti}_{45} \mathrm{Zr}_{5} \mathrm{Cu}_{45} \mathrm{Ni}_{5}$ metallic glass in which 1 at\% Ta was substituted for $\mathrm{Cu}$ exhibited the highest plasticity, with plastic strain of $3.1 \%$. Al substitution induced precipitation of larger crystalline grains, resulting

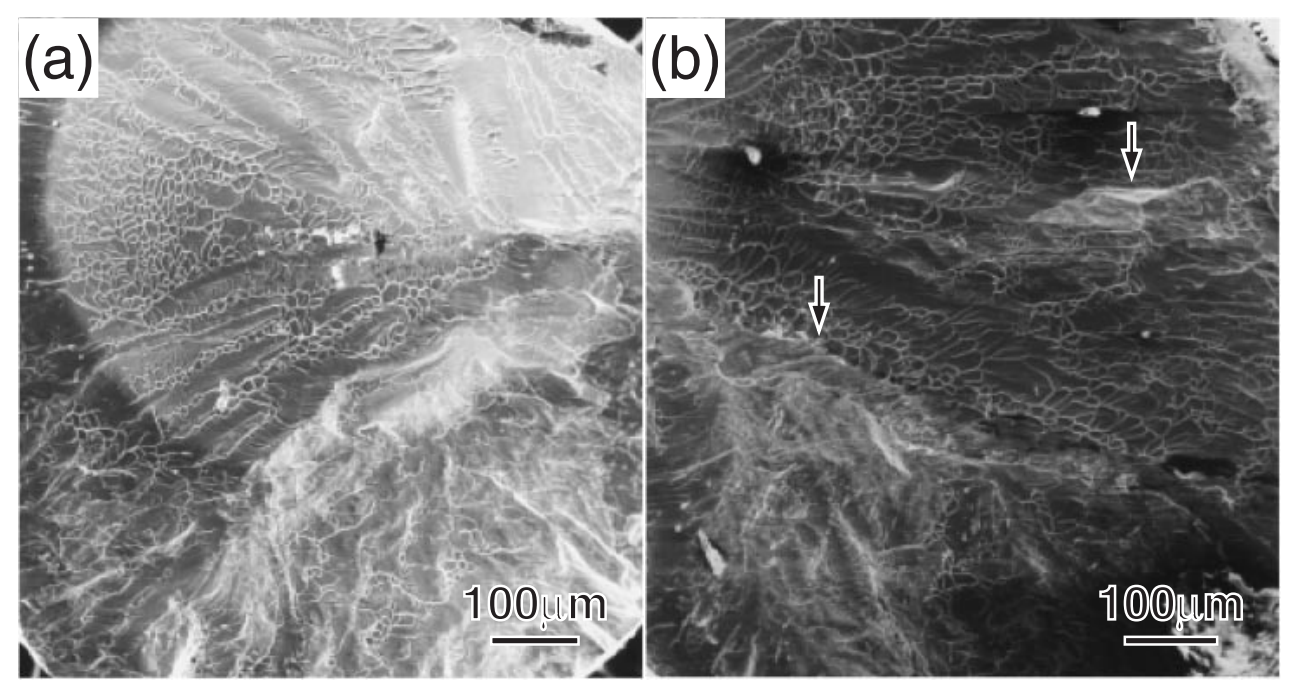

Fig. 5 Fracture surfaces of bulk specimens of (a) $\mathrm{Ti}_{45} \mathrm{Zr}_{5} \mathrm{Cu}_{44} \mathrm{Ni}_{5} \mathrm{Ta}_{1}$ and (b) $\mathrm{Ti}_{45} \mathrm{Zr}_{5} \mathrm{Cu}_{42} \mathrm{Ni}_{5} \mathrm{Al}_{3}$ after compression tests. Arrows in (b) indicate areas in which vein patterns are absent. 
in less of an improvement in plasticity. Dense and homogeneous dispersion of fine nanocrystals within a metallic glass matrix was found to be the main factors contributing to an improvement in the plasticity of Ti-based metallic glasses.

\section{Acknowledgments}

Part of this work was carried out at COE Laboratory, Institute for Materials Research, Tohoku University, and using several instruments supported by Research and Development Project on Advanced Metallic Glasses, Inorganic Materials and Joining Technology of the same institute. This work was supported by a Grant-in-Aid for Scientific Research on Priority Areas under the title "Materials Science of Bulk Metallic Glasses", and by a Grant-in-Aid for Young Scientists (B) 17760556 from the Ministry of Education, Culture, Sports, Science and Technology of Japan.

\section{REFERENCES}

1) C. Suryanarayana, A. Inoue and T. Masumoto: J. Mater. Sci. 15 (1980) 1993.

2) D. E. Polk, A. Calka and B. C. Giessen: Acta Metall. 26 (1978) 1097.

3) T. Zhang, A. Inoue and T. Masumoto: Mater. Lett. 15 (1993) 379.

4) A. Peker and W. L. Johnson: Appl. Phys. Lett. 63 (1993) 2342-2344.

5) X. H. Lin and W. L. Johnson: J. Appl. Phys. 78 (1995) 6514-6519.

6) C. Ma, H. Soejima, S. Ishihara, K. Amiya, N. Nishiyama and A. Inoue: Mater. Trans. 45 (2004) 3223-3227.

7) A. Inoue, N. Nishiyama, K. Amiya, T. Zhang and T. Masumoto: Mater. Lett. 19 (1994) 131-135.

8) T. Zhang and A. Inoue: Mater. Trans., JIM 39 (1998) 1001-1006.

9) T. Zhang and A. Inoue: Mater. Sci. and Eng. A304-306 (2001) 771774.

10) J. M. Park, Y. C. Kim, W. T. Kim and D. H. Kim: Mater. Trans. 45 (2004) 595-598.

11) H. Men, S. Pang, A. Inoue and T. Zhang: Mater. Trans. 46 (2005) 2218-2220.

12) M. X. Xia, C. L. Ma, H. X. Zheng and J. G. Li: Mater. Sci. Eng. A390 (2005) 372-375. 